\title{
Survey of bacterial diversity in chronic wounds using Pyrosequencing, DGGE, and full ribosome shotgun sequencing Scot E Dowd*1, Yan Sun ${ }^{2}$, Patrick R Secor ${ }^{3}$, Daniel D Rhoads ${ }^{2}$, Benjamin M Wolcott ${ }^{2}$, Garth A James ${ }^{3}$ and Randall D Wolcott ${ }^{2}$
}

Address: ${ }^{1}$ United States Department of Agriculture ARS Livestock Issues Research Unit, Lubbock, TX, USA, ${ }^{2}$ Medical Biofilm Research Institute, Lubbock, TX, USA and ${ }^{3}$ Center for Biofilm Engineering, Montana State University, Bozeman, MT, USA

Email: Scot E Dowd* - sdowd@lbk.ars.usda.gov; Yan Sun - s_yan_99@yahoo.com; Patrick R Secor - psecor@erc.montana.edu; Daniel D Rhoads - danrhoads@gmail.com; Benjamin M Wolcott - glorfindelvsp@yahoo.com; Garth A James - GJames@erc.montana.edu; Randall D Wolcott - randy@randallwolcott.com

* Corresponding author

Published: 6 March 2008

BMC Microbiology 2008, 8:43 doi:10.1/86/147|-2/80-8-43
Received: 25 October 2007

Accepted: 6 March 2008

This article is available from: http://www.biomedcentral.com/I47I-2I80/8/43

(c) 2008 Dowd et al; licensee BioMed Central Ltd.

This is an Open Access article distributed under the terms of the Creative Commons Attribution License (http://creativecommons.org/licenses/by/2.0), which permits unrestricted use, distribution, and reproduction in any medium, provided the original work is properly cited.

\begin{abstract}
Background: Chronic wound pathogenic biofilms are host-pathogen environments that colonize and exist as a cohabitation of many bacterial species. These bacterial populations cooperate to promote their own survival and the chronic nature of the infection. Few studies have performed extensive surveys of the bacterial populations that occur within different types of chronic wound biofilms. The use of 3 separate $16 \mathrm{~S}$-based molecular amplifications followed by pyrosequencing, shotgun Sanger sequencing, and denaturing gradient gel electrophoresis were utilized to survey the major populations of bacteria that occur in the pathogenic biofilms of three types of chronic wound types: diabetic foot ulcers $(D)$, venous leg ulcers $(V)$, and pressure ulcers $(P)$.

Results: There are specific major populations of bacteria that were evident in the biofilms of all chronic wound types, including Staphylococcus, Pseudomonas, Peptoniphilus, Enterobacter, Stenotrophomonas, Finegoldia, and Serratia spp. Each of the wound types reveals marked differences in bacterial populations, such as pressure ulcers in which $62 \%$ of the populations were identified as obligate anaerobes. There were also populations of bacteria that were identified but not recognized as wound pathogens, such as Abiotrophia para-adiacens and Rhodopseudomonas spp. Results of molecular analyses were also compared to those obtained using traditional culture-based diagnostics. Only in one wound type did culture methods correctly identify the primary bacterial population indicating the need for improved diagnostic methods.

Conclusion: If clinicians can gain a better understanding of the wound's microbiota, it will give them a greater understanding of the wound's ecology and will allow them to better manage healing of the wound improving the prognosis of patients. This research highlights the necessity to begin evaluating, studying, and treating chronic wound pathogenic biofilms as multi-species entities in order to improve the outcomes of patients. This survey will also foster the pioneering and development of new molecular diagnostic tools, which can be used to identify the community compositions of chronic wound pathogenic biofilms and other medical biofilm infections.
\end{abstract}




\section{Background}

Biofilms are well documented as medical problems associated with implants [1-9] and certain diseases [10-17]. However, the nature and importance of chronic wound pathogenic biofilms (CWPB) is only now beginning to be realized as reviewed and discussed in the scientific literature [18-25]. Chronic wounds, including diabetic foot ulcers (D), venous leg ulcers $(\mathrm{V})$, and pressure ulcers $(\mathrm{P})$, are often resistant to natural healing and require long term medical care [26-38]. Chronic wounds and their associated pathogenic biofilms [20,22,24,39-44] are also associated as a primary contributing factor in hundreds of thousands of annual deaths and billions of dollars in direct medical costs annually $[20,22,38,45-55]$.

For decades, medical microbiologists have relied on culture techniques to elucidate the complexity of infections including CWPB [56,57]. These techniques with only minor advancements have been used over the past 150 years and are currently the mainstay of the clinical microbiology laboratories. These culture methods can be used to identify the "culturable" bacteria associated with such biofilms. However, the use of laboratory culture techniques is typically only able to detect (as isolates) those organisms which grow relatively quickly and easily in laboratory media. This presents an important problem and descrepency because many of the bacteria in wound biofilms are recalcitrant to culture [58]. Thus, there is a lack of information about the diversity of populations that occur in association with CWPB. A better understanding of bacterial populations associated with CWPB is necessary to enable development of next generation management and therapeutics [59-62].

No studies have been identified which have utilized deep sequencing molecular methods (pyrosequencing) to evaluate the diversity of microbial populations that occur within the pathogenic biofilms associated with each of the three major types of chronic wounds. This report describes the first use of partial ribosomal amplification and pyrosequencing (PRAPS) to look at the microbial diversity in chronic wounds. Combined with two more traditional molecular methods; full ribosomal amplification, cloning and Sanger sequencing (FRACS) and partial ribosomal amplification, density gradient gel electrophoresis (DGGE) and Sanger sequencing (PRADS) we are providing a comprehensive survey of the microbial populations that are present in three types of chronic wound biofilms: venous leg ulcers, diabetic foot ulcers, and pressure ulcers. The compilation of data obtained with each of these methods provides one of the first comprehensive surveys of bacteria that are occur in three different types of chronic wound biofilms.

\section{Results and Discussion \\ Comparison of Molecular Methods and wound types}

It should be noted that this paper is not intended to contrast each of the molecular methods, or to purposefully compare wound types, but rather to detail the results of each individually in the hopes of gaining an understanding of the microbial diversity within pathogenic biofilms. Although this study could be used to compare or contrast the three molecular methods, we sought instead to use these relatively different strategies to better survey and report the diversity in the different types of wounds. A portion of the bias of one molecular method (e.g. due to primer specificity and universality) we intended to be somewhat compensated by the other methods, each of which utilize different "universal" $16 \mathrm{~S}$ primers. Another important note is that these analyses do not represent the diversity within a given wound from a single patient; instead these data represented diversity among a given chronic wound type. In-depth comparison of the populations between each wound type as part of this study would also have been outside the scope of the methodologies and experimental design employed. The primary observations that could be logically employed when comparing wound types are two-fold. Each wound type demonstrated populations and diversity that were markedly more prevalent than those seen in other wound types as discussed below. Each wound group also demonstrated a different level of oxygen tolerance among its bacterial populations (Figure 1). This second observation indicates there may be a common pathophysiology among wound types that likely affects the ecology of the wound environment and may play an important role in determining the bacterial genera that can become integrated as part of a wound biofilm. These observations obviously cannot be fully addressed within the scope of this survey yet they do provide important directions for future research.

\section{PRAPS}

The Rowher lab [63] was the first to pyrosequencing approaches to evaluate the diversity of complex microbial ecosystems by looking at environmentally isolated genome sequences from two sites in the Soudan Mine, Minnesota, USA. A few studies have utilized a PRAPS approach to evaluate the genetic diversity of clinical samples [64] or as as a form of clinical isolate genotyping [6569]. To date, PRAPS has not been used to evaluate the biodiversity of clinically infected biofilm samples, particularly CWPB.

A total of 193890 sequences were generated among the 4 samples including the pooled control sample of which over 129,000 sequences were utilized in the actual PRAPS analysis, gave a comprehensive functional survey of pathogenic biofilm populations within each wound type (Table 1). Facultative gram negative rods predominated in 


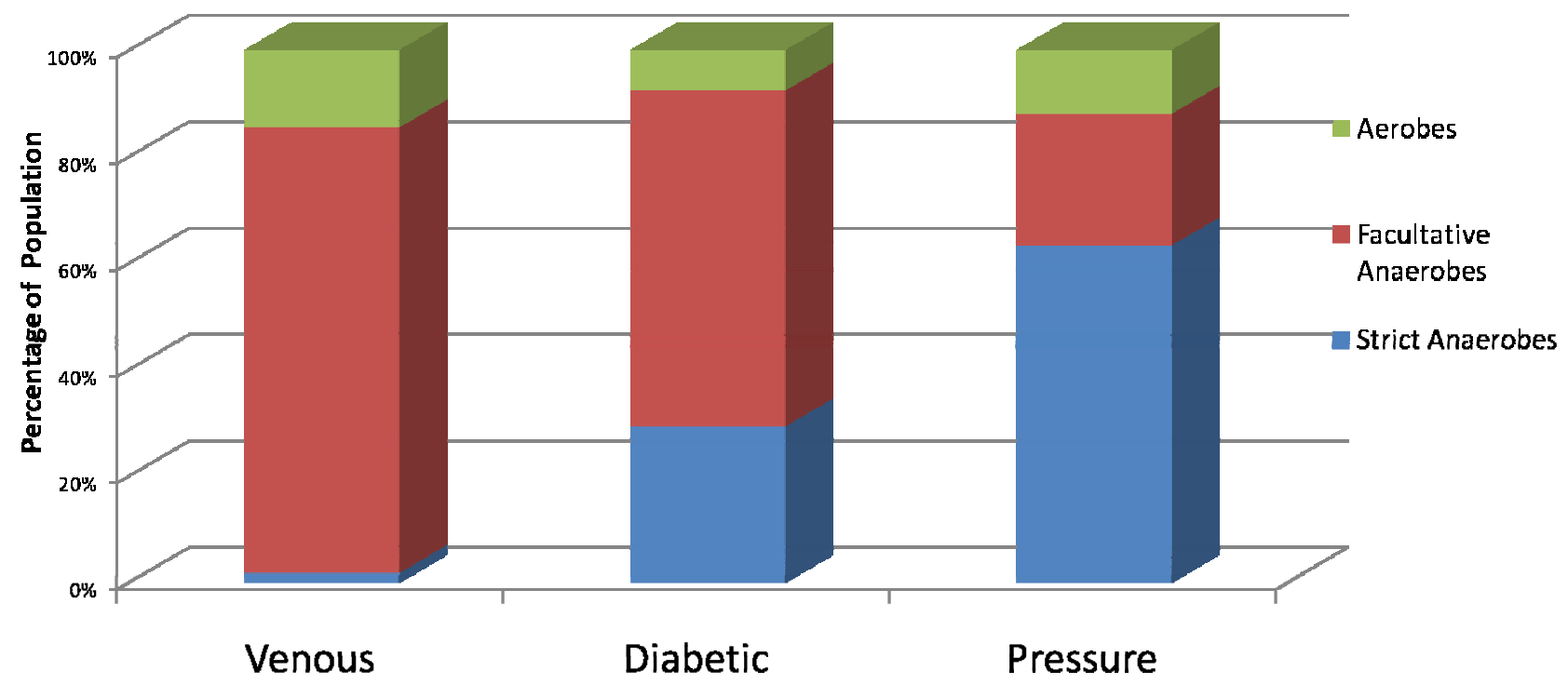

Figure I

Distribution of Bacterial Populations in Chronic Wounds in Relation to Aerotolerance. Diabetic, venous, or pressure ulcer types were analyzed separately using pyrosequencing and the resulting populations grouped into 3 catagories based upon their suggested aerotolerance. This figure graphically illustrates the relative distribution of these functional catagories among the wound types.

the $\mathrm{V}$ wounds. The predominant bacterial types in $\mathrm{V}$ biofilms were Enterobacter, Serratia, Stenotrophomonas, and Proteus spp. (Table 2). Strict anaerobes, cocci, and gram positives were scarce. In D samples the primary bacterial genera were Staphylococcus, Peptoniphilus, Rhodopseudomonas, Enterococcus, Veillonella, Clostridium, and Finegoldia spp. Facultative and strict anaerobic gram positive cocci were most prevalent (Table 3). Finally, in P samples, the predominant species were Peptoniphilus, Serratia, Peptococcus, Streptococcus, and Finegoldia spp. Thus, strict anaerobic gram positive cocci dominated the communities within P biofilms (Table 4).

\section{FRACS}

The use of Full Ribosomal Amplification, Cloning and Sanger Sequencing (FRACS) has been utilized for at least 18 years to evaluate the biodiversity of environmental samples [70-72]. This method has also been used to evaluate the microbial diversity of environmental biofilms [73] and at least one study utilized this approach to evaluate the microbial diversity of diabetic foot ulcers [74].

When using FRACS for 200 random clones from each library and following vector screening and quality scoring, we found that between 179 and 194 sequences from each

Table I: Overview of the phenotypes of microbial populations as determined using pyrosequencing (PRAPS).

\begin{tabular}{|c|c|c|c|c|c|c|}
\hline & $\begin{array}{r}\text { Pressure Ulcer } \\
\text { seq }\end{array}$ & $\begin{array}{r}\text { Pressure Ulcer } \\
\text { genus }\end{array}$ & $\begin{array}{r}\text { Diabetic Foot } \\
\text { Ulcer seq }\end{array}$ & $\begin{array}{r}\text { Diabetic Foot } \\
\text { Ulcer genus }\end{array}$ & $\begin{array}{r}\text { Venous Let } \\
\text { Ulcer seq }\end{array}$ & $\begin{array}{l}\text { Venous Leg } \\
\text { Ulcer genus }\end{array}$ \\
\hline Anaerobe & 17105 & 12 & 10519 & 15 & 523 & 6 \\
\hline Aerobe & $324 I$ & 9 & 2740 & 12 & 4402 & 9 \\
\hline $\begin{array}{l}\text { Facultative } \\
\text { anaerobes }\end{array}$ & 6686 & 15 & 22673 & 19 & 25226 & 16 \\
\hline Gram positive & $|875|$ & 18 & 22821 & 20 & 984 & 12 \\
\hline Gram negative & 8281 & 17 & 13111 & 26 & 29167 & 19 \\
\hline Rod & 8384 & 25 & 14682 & 34 & 29729 & 25 \\
\hline Cocci & 18648 & 12 & 21250 & 12 & 422 & 6 \\
\hline UWB & 440 & 8 & 656 & 7 & 1724 & 3 \\
\hline
\end{tabular}

The data from pyrosequencing (PRAPS) is broken down into the number of sequences (seq) from each sample associated with the indicated phenotypic characteristic (anaerobe, gram positive, etc). Also shown are the number of genera that were associated with each of the phenotypic categories. UWB refers to unknown wound bacteria or sequences without significant similarity to a database sequences. 
Table 2: Results obtained for venous leg ulcer sample using pyrosequencing (PRAPS). This table provides the identified genera of the bacteria found using pyrosequencing (PRAPS) in the $V$ sample, the number of sequences corresponding to a given genus, the known gram staining properties, the aerotolerance (anaerobic, anaerobic, or facultative anaerobic) nature of the genus, and the relative shape (rod or cocci) of the genus.

\begin{tabular}{|c|c|c|c|c|c|}
\hline Genus & Seq & $\%$ & Gram & Aerotolerance & Shape \\
\hline Enterobacter spp. & 14288 & 44.83 & - & Facultative anaerobe & Rod \\
\hline Serratia spp. $*^{*}$ & 6132 & 19.24 & - & Facultative anaerobe & Rod \\
\hline Stenotrophomonas spp. & 3532 & 11.08 & - & Aerobe & Rod \\
\hline Proteus spp. & 2469 & 7.75 & - & Facultative anaerobe & Rod \\
\hline UWB & 1446 & 4.54 & unk & Unk & Unk \\
\hline Proteus mirabilis. & 1080 & 3.39 & - & Facultative anaerobe & Rod \\
\hline Salmonella spp. & 739 & 2.32 & - & Facultative anaerobe & Rod \\
\hline Clostridium spp. & 408 & 1.28 & + & Anaerobe & Rod \\
\hline Alcaligenes faecalis & 337 & 1.06 & - & Aerobe & Rod \\
\hline UWB & 261 & 0.82 & unk & Unk & Unk \\
\hline Pseudomonas spp.* & 185 & 0.58 & - & Aerobe & Rod \\
\hline Staphylococcus spp.* & 143 & 0.45 & + & Facultative anaerobe & Cocci \\
\hline Brevundimonas diminuta & 123 & 0.39 & - & Aerobe & Rod \\
\hline Streptococcus spp. & 107 & 0.34 & + & Facultative anaerobe & Cocci \\
\hline Acinetobacter spp. & 102 & 0.32 & - & Aerobe & Rod \\
\hline Enterococcus spp. & 94 & 0.29 & + & Facultative anaerobe & Cocci \\
\hline Pantoea spp. & 81 & 0.25 & - & Facultative anaerobe & Rod \\
\hline Corynebacterium striatum* & 81 & 0.25 & + & Aerobe & Rod \\
\hline Peptoniphilus spp. & 65 & 0.20 & + & Anaerobe & Cocci \\
\hline E. coli & 31 & 0.10 & - & Facultative anaerobe & Rod \\
\hline Bacillus spp. & 25 & 0.08 & + & Aerobe & Rod \\
\hline Paenibacillus spp. & 24 & 0.08 & + & Facultative anaerobe & Rod \\
\hline Eubacterium spp. & 24 & 0.08 & + & Anaerobe & Rod \\
\hline Klebsiella spp. & 21 & 0.07 & - & Facultative anaerobe & Rod \\
\hline Xanthomonas spp. & 17 & 0.05 & - & Aerobe & Rod \\
\hline UWB & 17 & 0.05 & unk & Unk & Unk \\
\hline Ferrimonas spp. & 17 & 0.05 & - & Facultative anaerobe & Rod \\
\hline Finegoldia magna & 13 & 0.04 & + & Anaerobe & Cocci \\
\hline Dendrosporobacter quercicolus & 13 & 0.04 & - & Anaerobe & Rod \\
\hline
\end{tabular}

UWB refers to unknown wound bacteria or sequences without significant similarity to database sequences. * The asterisk identifies bacteria previously cultured from a single culture result from each subject's medical record from subjects in the $V$ pool. The only bacterium cultured that was not found using PRAPS was Citrobacter. The \% represents the percentage of the total sequences analyzed within the sample.

library could be analyzed. The break down of genotypes demonstrated similar trends (Table 5) as were observed using PRAPS. Strict anaerobes, cocci, and gram positives were scarce in the $\mathrm{V}$ group (Table 6 ). Facultative and strict anaerobic gram positive cocci were most prevalent in the D group (Table 7 ), and strictly anaerobic gram positive dominated the P group (Table 8). In V samples the predominant bacterial genus, identified by FRACS, were overwhelmingly Pseudomonas spp. (including $P$. aeruginosa and $P$. fluorescens) followed by Enterobacter spp. (including E. cloacae), Stenotrophomonas maltophilia, Proteus spp., and Staphyloccoccus aureus (Table 6). In the D sample the predominant species was overwhelmingly Staphylococcus aureus followed by Anaerococcus lactolyticus, Anaerococcus vaginalis, Bacterioides fragilis, Finegoldia magna, and Morganella morganii (Table 7). Finally, predominant bacteria in the P sample were Peptoniphilus ivorii, Anerococcus spp., Streptococcus dysgalactiae, and Peptoniphilus spp. (Table 8).

\section{PRADS}

The use of a Partial Ribosomal Amplification, DGGE, and Sanger sequencing (PRADS) has been utilized extensively to study microbial diversity [75-80]. This approach has also been used extensively to study the microbial diversity of biofilms [81-84] and has even been used to study clinical biofilms [85]. The primary use of DGGE by itself is to provide an indication of diversity. The number of bands seen in a gel, in many cases, can provide a relative measure of the number of different bacteria present. It is understood that each of the bands seen in a DGGE gel can represent multiple species and even the same species can be represented by multiple bands as we observed in the current study (data not shown).

By excising the predominant bands from each sample, cloning them into a vector, and sequencing them, the identity of the bacteria from each band are identified. In 
Table 3: Results obtained for diabetic foot ulcer sample using pyrosequencing (PRAPS).

\begin{tabular}{|c|c|c|c|c|c|}
\hline Genus & Seq & $\%$ & Gram & Aerotolerance & Shape \\
\hline Staphylococcus spp. & 10874 & 29.72 & + & Facultative anaerobe & Cocci \\
\hline Peptoniphilus spp. & 2555 & 6.98 & + & Anaerobic & Cocci \\
\hline RhodoPseudomonas spp. & $254 I$ & 6.94 & - & Facultative anaerobe & Rod \\
\hline Enterococcus spp. & 2341 & 6.40 & + & Facultative anaerobe & Cocci \\
\hline Veillonella spp. & 1978 & 5.41 & - & Anaerobic & Cocci \\
\hline Clostridium spp. & 1975 & 5.40 & + & Anaerobic & Rod \\
\hline Finegoldia magna & 1953 & 5.34 & + & Anaerobic & Cocci \\
\hline Haemophilus spp. & 1701 & 4.65 & - & Facultative anaerobe & Rod \\
\hline Acinetobacter spp. & $130 \mid$ & 3.56 & - & Aerobic & Rod \\
\hline Morganella spp. & 1240 & 3.39 & - & Facultative anaerobe & Rod \\
\hline Serratia spp. & 1125 & 3.07 & - & Facultative anaerobe & Rod \\
\hline Proteus spp. & 1072 & 2.93 & - & Facultative anaerobe & Rod \\
\hline Dialister spp. & 1029 & 2.81 & - & Anaerobic & Rod \\
\hline Streptococcus spp. & 751 & 2.05 & + & Facultative anaerobe & Cocci \\
\hline Stenotrophomonas spp. & 669 & 1.83 & + & Aerobe & Rod \\
\hline Peptococcus niger & 588 & 1.61 & + & Anaerobic & Cocci \\
\hline UWB & 342 & 0.93 & unk & Unk & Unk \\
\hline Klebsiella spp. & 326 & 0.89 & - & Facultative anaerobe & Rod \\
\hline Actinomyces spp. & 307 & 0.84 & + & Facultative anaerobe & Rod \\
\hline Gordonia spp. & 302 & 0.83 & + & Aerobic & Rod \\
\hline Delftia spp. & 251 & 0.69 & - & Aerobic & Rod \\
\hline Gemella spp. & 168 & 0.46 & + & Anaerobic & Cocci \\
\hline Corynebacterium spp. & 157 & 0.43 & + & Facultative anaerobe & Rod \\
\hline UWB & 143 & 0.39 & unk & Unk & Unk \\
\hline UWB & 107 & 0.29 & unk & Unk & Unk \\
\hline Salmonella enterica & 102 & 0.28 & - & Facultative anaerobe & Rod \\
\hline Fusobacterium spp. & 99 & 0.27 & - & Anaerobic & Rod \\
\hline Varibaculum cambriense & 54 & 0.15 & + & Anaerobic & Rod \\
\hline Enterobacter spp. & 52 & 0.14 & - & Facultative anaerobe & Rod \\
\hline Bacillus spp. & 51 & 0.14 & + & aerobic & Rod \\
\hline Eikenella spp. & 42 & 0.11 & - & facultative anaerobe & Rod \\
\hline Anaerococcus spp. & 42 & 0.11 & + & anaerobic & Cocci \\
\hline Hydrogenophaga spp. & 40 & 0.11 & - & aerobic & Rod \\
\hline Alcaligenes faecalis & 36 & 0.10 & - & aerobic & Rod \\
\hline E coli & 32 & 0.09 & - & facultative anaerobe & Rod \\
\hline Sphingomonas spp. & 26 & 0.07 & - & aerobic & Rod \\
\hline Acidovorax spp. & 26 & 0.07 & - & aerobic & Rod \\
\hline Prevotella spp. & 22 & 0.06 & - & anaerobic & Rod \\
\hline UWB & 20 & 0.05 & unk & unk & Unk \\
\hline Eubacterium spp. & 20 & 0.05 & + & anaerobic & Rod \\
\hline Bacteroides spp. & 20 & 0.05 & - & anaerobic & Rod \\
\hline UWB & 17 & 0.05 & unk & unk & Unk \\
\hline UWB & 16 & 0.04 & unk & unk & Unk \\
\hline Selenomonadaceae spp. & 16 & 0.04 & - & anaerobic & Rod \\
\hline Brevibacterium spp. & 14 & 0.04 & + & aerobic & Rod \\
\hline Riemerella spp. & 13 & 0.04 & - & aerobic & Rod \\
\hline UWB & II & 0.03 & unk & unk & Unk \\
\hline Bradyrhizobium spp. & II & 0.03 & - & aerobic & Rod \\
\hline Pantoea agglomerans & 10 & 0.03 & - & facultative anaerobe & Rod \\
\hline
\end{tabular}

This table provides the identified genus of the bacteria found using pyrosequencing (PRAPS) in the D sample, the number of sequences corresponding to this genus, the known gram staining properties, the aerotolerance (anaerobic, anaerobic, or facultative anaerobic) nature of the genus, and the shape of the genus. UWB refers to unknown wound bacteria or sequences without significant similarity to database sequences. * The asterisk identifies bacteria previously cultured from a single culture result from each subject's medical record from subjects in the diabetic foot ulcer pool (D sample). Bacteria that were cultured and were not found using PRAPS include Citrobacter and Pseudomonas. \% represents the percentage of the total sequences analyzed within the sample. 
Table 4: Results obtained for the pressure ulcer sample (P) using pyrosequencing (PRAPS).

\begin{tabular}{|c|c|c|c|c|c|}
\hline Genus & Seq & $\%$ & Gram & Aerotolerance & Shape \\
\hline Peptoniphilus spp. & 10543 & 38.38 & + & Anaerobe & Cocci \\
\hline Serratia spp. & 5234 & 19.05 & - & facultative anaerobe & Rod \\
\hline Peptococcus niger. & 3042 & 11.07 & + & anaerobe & Cocci \\
\hline Streptococcus spp. & 3016 & 10.98 & + & facultative anaerobe & Cocci \\
\hline Finegoldia magna & 1743 & 6.34 & + & anaerobe & Cocci \\
\hline Dialister spp. & 1374 & 5.00 & - & anaerobe & rod \\
\hline Pectobacterium spp. & 528 & 1.92 & - & facultative anaerobe & rod \\
\hline Enterobacter spp. & 392 & 1.43 & - & facultative anaerobe & rod \\
\hline Proteus spp. & 308 & 1.12 & - & facultative anaerobe & $\operatorname{rod}$ \\
\hline Veillonella spp. & 186 & 0.68 & - & anaerobe & cocci \\
\hline UWB & $|4|$ & 0.51 & Unk & unk & unk \\
\hline UWB & 121 & 0.44 & Unk & unk & unk \\
\hline Clostridium spp. & 93 & 0.34 & + & anaerobe & rod \\
\hline Corynebacterium striatum & 73 & 0.27 & + & aerobe & rod \\
\hline Delftia spp. & 65 & 0.24 & - & aerobe & rod \\
\hline UWB & 63 & 0.23 & Unk & unk & unk \\
\hline Enterococcus spp. & 62 & 0.23 & + & facultative anaerobe & cocci \\
\hline Staphylococcus spp. & 56 & 0.20 & + & facultative anaerobe & cocci \\
\hline Hydrogenophaga spp. & 54 & 0.20 & - & aerobe & rod \\
\hline Eggerthella lenta & 33 & 0.12 & + & anaerobe & rod \\
\hline UWB & 31 & 0.11 & Unk & unk & unk \\
\hline UWB & 31 & 0.11 & Unk & unk & unk \\
\hline Prevotella spp. & 31 & 0.11 & - & anaerobe & rod \\
\hline Varibaculum cambriense & 28 & 0.10 & + & anaerobe & rod \\
\hline Actinomyces europaeus & 28 & 0.10 & + & facultative anaerobe & rod \\
\hline Ferrimonas spp. & 27 & 0.10 & - & facultative anaerobe & rod \\
\hline Bacillus spp. & 24 & 0.09 & + & aerobe & rod \\
\hline UWB & 22 & 0.08 & Unk & unk & unk \\
\hline Fusobacterium spp. & 22 & 0.08 & - & anaerobe & rod \\
\hline Alcaligenes faecalis & 20 & 0.07 & - & aerobe & rod \\
\hline UWB & 17 & 0.06 & Unk & unk & unk \\
\hline Riemerella spp. & 15 & 0.05 & - & aerobe & rod \\
\hline UWB & 14 & 0.05 & Unk & unk & unk \\
\hline Stenotrophomonas spp. & 14 & 0.05 & - & aerobe & rod \\
\hline Shewanella spp. & 11 & 0.04 & - & facultative anaerobe & rod \\
\hline Eubacterium spp. & 10 & 0.04 & + & anaerobe & rod \\
\hline
\end{tabular}

This table provides the identified genus of the bacteria found using pyrosequencing (PRAPS) in the P sample, the number of sequences corresponding to this genus, the known gram staining properties, the aerotolerance (anaerobic, anaerobic, or facultative anaerobic) nature of the genus, and the shape of the genus. UWB refers to unknown wound bacteria or sequences without significant similarity to database sequences. $*$ The asterisk identifies bacteria previously cultured from a single culture result from each subject's medical record from subjects in the $P$ pool. Bacteria that were cultured and were not found using PRAPS include Acinetobacter, Leclercia, Morganella, and Pseudomonas. The \% represents the percentage of the total sequences analyzed within the sample.

the V sample the primary bacteria were Enterobacter, Pseudomonas, and Proteus spp. (Table 9). This is similar to the results seen using both FRACSS and PRAPS. In the D sample, PRADS identified Pseudomonas, Haemophilus, Citrobacter, and Stenotrophomonas as the predominant species (Table 9). In the P sample the primary species identified was Serratia, Dialister, and Peptococcus spp. (Table 9).

\section{Culturing}

A review of the literature identifies Staphylococcus spp. as the predominant organisms associated with wounds based upon culturing [86-88]. As discussed in the intro- duction, this is primarily due to the ability of this bacterium to be propagated in culture media under typical laboratory conditions. Pseudomonas spp., another easy to culture bacteria is also frequently isolated from chronic wounds using culture methods $[89,90]$. Other species that have been most consistently identified in association with chronic wounds include E. coli, Enterobacter cloacae, Klebsiella, Streptococcus, Enterococcus. and Proteus spp. $[25,58,86,88,90-95]$. One notable commonality of the above organisms is the ease with which they can be cultured in standard laboratory growth media under aerobic conditions. These claims are upheld by the data presented 
Table 5: Overview of the phenotypes of microbial populations as determined using shotgun Sanger sequencing (FRACS).

\begin{tabular}{|c|c|c|c|c|c|c|}
\hline Category & $\begin{array}{r}\begin{array}{r}\text { Pressure Ulcer } \\
\text { seq }\end{array} \\
\end{array}$ & $\begin{array}{r}\text { Pressure Ulcer } \\
\text { sp. }\end{array}$ & $\begin{array}{l}\text { Diabetic Foot } \\
\text { Ulcer seq. }\end{array}$ & $\begin{array}{r}\text { Diabetic Foot } \\
\text { Ulcer sp. }\end{array}$ & $\begin{array}{r}\text { Venous Leg } \\
\text { Ulcer seq }\end{array}$ & $\begin{array}{l}\text { Venous Leg } \\
\text { Ulcer sp. }\end{array}$ \\
\hline aerobes & 20 & 5 & I & I & 114 & 7 \\
\hline $\begin{array}{l}\text { facultative } \\
\text { anaerobes }\end{array}$ & 21 & 8 & 102 & 15 & 69 & 15 \\
\hline anaerobes & 143 & 13 & 75 & 15 & 7 & 3 \\
\hline Cocci & 136 & 11 & 137 & 14 & 14 & 6 \\
\hline Rods & 48 & 15 & 41 & 17 & 176 & 19 \\
\hline gram positive & 153 & 14 & 136 & 15 & 21 & 9 \\
\hline gram negative & 31 & 12 & 42 & 17 & 169 & 16 \\
\hline UWB & 2 & 2 & 0 & 0 & 4 & 4 \\
\hline
\end{tabular}

The data from Sanger sequencing (FRACS) is broken down into the number of sequences (seq) from each sample (P, D, and V) that were related to a given characteristic (anaerobe, gram positive etc). Also shown are the number of genera that were associated with each of the phenotypic categories. UWB refers to unknown wound bacteria or sequences without significant similarity to database sequences.

Table 6: Results obtained for venous leg ulcer sample (V) using shotgun Sanger sequencing (FRACS).

\begin{tabular}{|c|c|c|c|c|c|}
\hline Genus species & Number seq & $\%$ & Gram & Aerotolerance & Shape \\
\hline Pseudomonas sp*. & 45 & 23.20 & - & aerobic & rod \\
\hline Pseudomonas aeruginosa.* & 30 & 15.46 & - & aerobic & rod \\
\hline Pseudomonas fluorescens* & 20 & 10.31 & - & aerobic & rod \\
\hline Enterobacter spp. & 19 & 9.79 & - & facultative & rod \\
\hline Stenotrophomonas maltophilia. & 14 & 7.22 & - & aerobic & rod \\
\hline Enterobacter cloacae & 10 & 5.15 & - & facultative & rod \\
\hline Staphylococcus aureus* & 7 & 3.61 & + & Facultative anaerobe & cocci \\
\hline Proteus vulgaris & 6 & 3.09 & - & Facultative anaerobe & rod \\
\hline Shewanella algae & 6 & 3.09 & - & Facultative anaerobe & rod \\
\hline Proteus mirabilis. & 6 & 3.09 & - & Facultative anaerobe & rod \\
\hline UWB & 4 & 2.06 & unk & unk & unk \\
\hline Clostridium perfringens & 4 & 2.06 & + & anaerobic & rod \\
\hline Klebsiella spp.* & 4 & 2.06 & - & facultative & rod \\
\hline Serratia marcescens * & 3 & 1.55 & - & aerobic & rod \\
\hline Clostridium spp. & 2 & 1.03 & + & anaerobic & rod \\
\hline Helcococcus kunzii & 2 & 1.03 & + & facultative anaerobe & cocci \\
\hline Staphylococcus spp.* & 2 & 1.03 & + & Facultative anaerobe & cocci \\
\hline Enterobacter aerogenes & 2 & 1.03 & - & Facultative anaerobe & rod \\
\hline Bacillus fusiformis. & I & 0.52 & + & aerobic & rod \\
\hline Enterococcus avium* & I & 0.52 & + & Facultative anaerobe & cocci \\
\hline Enterococcus faecalis* & I & 0.52 & + & Facultative anaerobe & cocci \\
\hline Peptococcus spp. & I & 0.52 & + & anaerobic & cocci \\
\hline Achromobacter xylosoxidans & I & 0.52 & - & aerobic & rod \\
\hline Salmonella spp. & I & 0.52 & - & Facultative anaerobe & rod \\
\hline Escherichia coli & 1 & 0.52 & - & Facultative anaerobe & rod \\
\hline Shigella spp. & i & 0.52 & - & Facultative anaerobe & rod \\
\hline
\end{tabular}

This table provides the identified genera of the bacteria found using shotgun Sanger sequencing (FRACS) in the $V$ sample, the number of sequences corresponding to this genus, the known gram staining properties, the aerotolerance (anaerobic, anaerobic, or facultative anaerobic) nature of the genus, and the shape of the genus. UWB refers to unknown wound bacteria or sequences without significant similarity to database sequences. The asterisk * identifies bacteria previously cultured from a single culture result from each subject's medical record from subjects in the $V$ pool. Bacteria that were cultured and were not found using FRACSS include Acinetobacter, Citrobacter, and Corynebacterium. The \% represents the percentage of the total sequences analyzed within the sample. 
Table 7: Results obtained for diabetic foot ulcer sample (D) using shotgun Sanger sequencing (FRACS).

\begin{tabular}{|c|c|c|c|c|c|}
\hline Genus species & Seq & $\%$ & Gram & Aerotolerance & Shape \\
\hline Staphylococcus aureus $*$ & 70 & 39.33 & + & facultative & Cocci \\
\hline Anaerococcus lactolyticus & 16 & 8.99 & + & anaerobic & Cocci \\
\hline Anaerococcus vaginalis & 15 & 8.43 & + & anaerobic & cocci \\
\hline Bacterioides fragilis & 7 & 3.93 & - & anaerobic & rod \\
\hline Finegoldia magna & 6 & 3.37 & + & anaerobic & cocci \\
\hline Morganella morganii & 5 & 2.81 & - & Facultative anaerobe & rod \\
\hline Enterococcus faecalis* & 5 & 2.81 & + & facultative & cocci \\
\hline Peptoniphilus harei & 5 & 2.81 & + & anaerobic & cocci \\
\hline Clostridium novyi & 4 & 2.25 & + & anaerobic & rod \\
\hline Veillonella atypica & 4 & 2.25 & - & anaerobic & cocci \\
\hline Abiotrophia para-adiacens & 4 & 2.25 & + & anaerobic & cocci \\
\hline Veillonella parvula & 4 & 2.25 & - & anaerobic & cocci \\
\hline Citrobacter murliniae $*$ & 3 & 1.69 & - & facultative anaerobe & rod \\
\hline Haemophilus spp. & 3 & 1.69 & - & facultative & rod \\
\hline Clostridium spp. & 3 & 1.69 & + & anaerobic & rod \\
\hline Haemophilus segnis & 3 & 1.69 & - & faculative & $\operatorname{rod}$ \\
\hline Enterococcus avium* & 3 & 1.69 & + & facultative & cocci \\
\hline Proteus spp.* & 2 & 1.12 & - & Facultative anaerobe & rod \\
\hline Enterobacter aerogenes & 2 & 1.12 & - & facultative & rod \\
\hline Dialister spp. & 2 & 1.12 & - & anaerobic & rod \\
\hline Peptoniphilus asaccharolyticus & 2 & 1.12 & + & anaerobic & cocci \\
\hline Enterobacter cloacae & I & 0.56 & - & Facultative anaerobe & rod \\
\hline Klebsiella oxytoca* & I & 0.56 & - & Facultative anaerobe & rod \\
\hline Escherichia coli & I & 0.56 & - & facultative & rod \\
\hline Pseudoalteromonas spp. & 1 & 0.56 & - & facultative & rod \\
\hline Porphyromonas levii & I & 0.56 & - & anaerobic & rod \\
\hline Delftia acidovorans & I & 0.56 & - & aerobic & rod \\
\hline Dialister invisus & I & 0.56 & - & anaerobic & $\operatorname{rod}$ \\
\hline Staphylococcus epidermidis* & I & 0.56 & + & facultative & cocci \\
\hline Staphylococcus spp.* & 1 & 0.56 & + & facultative & cocci \\
\hline Granulicatella spp. & I & 0.56 & + & anaerobic & cocci \\
\hline
\end{tabular}

This table provides the identified genera of the bacteria found using shotgun Sanger sequencing (FRACS) in the D sample, the number of sequences corresponding to this genus, the known gram staining properties, the aerotolerance (anaerobic, anaerobic, or facultative anaerobic) nature of the genus, and the shape of the genus. The asterisk * identifies bacteria previously cultured from a single culture result from each subject's medical record from subjects in the D pool. Bacteria that were cultured and were not found using FRACSS include Pseudomonas, Serratia, and Streptococcus. The $\%$ represents the percentage of the total sequences analyzed within the sample.

here, as all of the isolates identified using the clinical cultures are relatively easy to propogate under aerobic conditions in standard laboratory media (Table 10).

Culture results for 29 of the 30 subjects were found by auditing the subjects' past and current longitudinal medical records. The bacteria isolated are indicated for comparative purposes in Tables 2, 3, 4 and 6, 7, 8 and reported fully in Table 10. Cultures were positive for some bacteria that were not identified using PRAPS, FRACS, or PRADS. In the $\mathrm{V}$ group, Citrobacter was identified via culture and was not discovered with molecular methods. In the $\mathrm{D}$ group, all bacteria that were cultured were identified using molecular methods. In the $\mathrm{P}$ group, Acinetobacter and Escherichia spp. were cultured but not identified via molecular methods. As noted in the methods, the samples used for culturing were not necessarily collected in parallel with the samples collected for molecular analyses.
Continuous longitudinal attempts to culture anaerobic bacteria had also been made and were unsuccessful for any of these patients. This highlights the problems with laboratory culture methods especially with the $\mathrm{P}$ type chronic wound, which is predicted to be primarily anaerobic using each of the molecular methods.

\section{Comparison to normal flora}

The microbial flora of normal skin is also considered complex. A bacterial diversity study of normal skin flora from 6 healthy subjects was performed using molecular methods [96]. It was found that there were hundreds of bacterial species among the individuals. The conclusions of this study indicated that normal flora of skin is highly diverse and only a few bacteria are common among the individuals. These included Propionibacteria, Corynebacteria, Staphylococcus, and Streptococcus spp. [96]. These results were largely corroborated by a previous study which collected 
Table 8: Results obtained for the pressure ulcer sample (P) using shotgun Sanger sequencing (FRACS).

\begin{tabular}{|c|c|c|c|c|c|}
\hline Genus species & Seq & $\%$ & Gram & Aerotolerance & Shape \\
\hline Peptoniphilus ivorii & 51 & 27.42 & + & anaerobic & cocci \\
\hline Anaerococcus lactolyticus & 20 & 10.75 & + & anaerobic & cocci \\
\hline Anaerococcus vaginalis & 16 & 8.60 & + & anaerobic & cocci \\
\hline Streptococcus dysgalactiae* & 14 & 7.53 & + & facultative & cocci \\
\hline Peptoniphilus harei & 14 & 7.53 & + & anaerobic & cocci \\
\hline Peptococcus niger & 12 & 6.45 & + & anaerobic & rod \\
\hline Serratia marcescens & 12 & 6.45 & - & aerobic & rod \\
\hline Finegoldia magna & 10 & 5.38 & + & anaerobic & cocci \\
\hline Peptoniphilus indolicus & 7 & 3.76 & + & anaerobic & cocci \\
\hline Clostridium hathewayi & 4 & 2.15 & + & anaerobic & rod \\
\hline Prevotella buccalis & 3 & 1.61 & - & anaerobic & rod \\
\hline Pseudomonas aeruginosa* & 3 & 1.61 & - & aerobic & rod \\
\hline UWB & 2 & 1.08 & Unk & unk & unk \\
\hline Dialister invisus & 2 & 1.08 & - & anaerobic & rod \\
\hline Dialister spp. & 2 & 1.08 & - & anaerobic & rod \\
\hline Delftia acidovorans & 2 & 1.08 & - & aerobic & rod \\
\hline Pseudomonas fluorescens* & 2 & 1.08 & - & aerobic & rod \\
\hline Helcococcus kunzii & I & 0.54 & + & facultative anaerobe & cocci \\
\hline Enterococcus faecalis* & 1 & 0.54 & + & facultative & cocci \\
\hline Staphylococcus epidermidis* & 1 & 0.54 & + & facultative & cocci \\
\hline Streptococcus pyogenes* & 1 & 0.54 & + & facultative & cocci \\
\hline Clostridium perfringens & I & 0.54 & + & anaerobic & rod \\
\hline Klebsiella granulomatis & I & 0.54 & - & Facultative anaerobe & rod \\
\hline Klebsiella pneumoniae & I & 0.54 & - & Facultative anaerobe & rod \\
\hline Proteus vulgaris* & I & 0.54 & - & Facultative anaerobe & rod \\
\hline Porphyromonas uenonis & I & 0.54 & - & anaerobic & rod \\
\hline Pseudomonas spp.* & I & 0.54 & - & aerobic & rod \\
\hline
\end{tabular}

This table provides the identified genera of the bacteria found using shotgun Sanger sequencing (FRACS) in the $P$ sample, the number of sequences corresponding to the given genus, the known gram staining properties, the aerotolerance (anaerobic, anaerobic, or facultative anaerobic) nature of the genus, and the shape of the genus. UWB refers to unknown wound bacteria or sequences without significant similarity to database sequences. The asterisk * identifies bacteria previously cultured from a single culture result from each subject's medical record from subjects in the P pool. Bacteria that were cultured and were not found using FRACSS include Acinetobacter, Enterobacter, Leclercia and Morganella. The \% represents the percentage of the total sequences analyzed within the sample.

and analyzed swabs from the forehead of 5 individuals. This study also found Staphylococcus and Propionibacteria spp. as well as high prevalence of methylophilus spp. [97]. Few other studies were found evaluating normal skin microflora suggesting that more extensive studies of healthy skin microflora are also needed. The primary bacteria that occur on healthy skin also correlate to the primary bacteria cultured from wound biofilms. Future studies are needed to evaluate the normal flora and chronic wound biofilm flora from the same patients.

\section{Anaerobes in pathogenic biofilms}

In relation to anaerobes, the literature is now beginning to show their importance in chronic wound pathogenic biofilms. Even though such wounds are typically exposed to air [88] anaerobes may be most prevelant physiological type for a given wound or a given wound type as shown in this study. Many of these newer studies show the importance of anaerobes such as Peptostreptococcus, Prevotella, Finegoldia and Peptoniphilus spp. [88,89,91,93,94,98], which were also seen as important in the current survey.
However, as noted previously, only a few studies have looked at the populations of bacteria in various wound types. Bowler et al [88] evaluated venous leg ulcers using cultural isolation techniques that included special considerations for the propogation of anaerobes. They found that anaerobes represented $49 \%$ of the total microbial composition in such wounds. This does not agree with our analyses of the V type ulcer, which showed only $1.6 \%$ of sequences were matched to anaerobes. However, almost $30 \%$ of the sequences from $\mathrm{D}$ and $62 \%$ of sequences from $\mathrm{P}$ wound types were matched to anaerobes. An interesting observation is that the differences in the functional diversity of the pathogenic biofilms may suggest important differences in the physiology of these three types of wounds. As indicated previously, the pathophysiology of a wound type may select for certain physiological or functional populations within the associated pathogenic biofilm. Thus, the bacterial populations which are prevelant might in turn suggest differences in management of the individual CWPB are necessary. 
Table 9: Results obtained for each of the samples using DGGE band extraction and sequencing (PRADS).

\begin{tabular}{|c|c|c|c|c|c|}
\hline V seq & V genus & D seq & D genus & P seq & P genus \\
\hline 18 & Enterobacter spp.* & 13 & Pseudomonas spp.* & 34 & Serratia spp. \\
\hline 17 & Pseudomonas spp.* & 12 & Haemophilus spp. & 13 & Dialister spp. \\
\hline 4 & Proteus spp. & 11 & Citrobacter spp.* & 10 & Peptococcus spp. \\
\hline 2 & Klebsiella spp.* & 11 & Stenotrophomonas spp. & 3 & Pseudomonas spp.* \\
\hline 2 & Pectobacterium spp. & 10 & Morganella spp. & 2 & Citrobacter spp. \\
\hline 2 & Erwinia spp. & 10 & Staphylococcus spp. & 2 & Morganella spp. \\
\hline I & Serratia spp.* & 5 & Acinetobacter spp. & 2 & Proteus spp.* \\
\hline I & UWB & 5 & Acinetobacter spp. & I & Haemophilus spp. \\
\hline \multirow[t]{17}{*}{ I } & Haemophilus spp. & 4 & Morganella spp. & I & Klebsiella spp. \\
\hline & & 4 & Proteus spp.* & I & Leminorella spp. \\
\hline & & 3 & Delftia spp. & I & Pectobacterium spp. \\
\hline & & 3 & Obesumbacterium spp. & I & Peptoniphilus spp. \\
\hline & & 2 & Dialister spp. & I & Prevotella spp. \\
\hline & & 2 & Mannheimia spp. & I & UWB \\
\hline & & I & Comamonas spp. & & \\
\hline & & I & Grimontia spp. & & \\
\hline & & I & Klebsiella spp.* & & \\
\hline & & I & Macrococcus spp. & & \\
\hline & & 1 & Methylophaga spp. & & \\
\hline & & I & Pantoea spp. & & \\
\hline & & I & Pectobacterium spp. & & \\
\hline & & I & Rahnella spp. & & \\
\hline & & I & Serratia spp.* & & \\
\hline & & I & Streptococcus spp.* & & \\
\hline & & I & UWB & & \\
\hline
\end{tabular}

This table provides the identified genus of the bacteria found in each of the samples as determined by DGGE band excision, cloning and sequencing (PRADS). The number of sequences corresponding to this genus is provided. The physiological aspects of these isolates are described elsewhere in most cases. UWB refers to unknown wound bacteria or sequences without significant similarity to database sequences.

As has been demonstrated in the laboratory [59,99], anaerobes may cope with the toxic effects of oxygen by interacting with aerobic or facultative anaerobic bacterial populations in a symbiotic manner as part of a process known as coaggregation. Aerobic species may consume oxygen and create localized environments, allowing the obligate anaerobes to gain advantage when in close proximity. The Lewandowski lab has also shown that oxygen only penetrates microns into the surface of biofilms sug- gesting that internal regions may support only anaerobes and facultative anaerobes [100]. Such synergistic interactions and advantages of biofilm phenotype have been shown for specific aerobes and anaerobes. Using animal models it has also been shown that mixtures of anaerobic and aerobic bacteria have been shown to produce disease states which cannot be reproduced by the individual species alone [61,101-104,104,105]. These findings suggest a complexity to the host-pathogen interaction that adds a

Table I0: Bacteria cultured during standard of care from three wound groups.

\begin{tabular}{|c|c|c|c|c|c|}
\hline Subjects & V group & Subjects & D group & Subjects & P group \\
\hline 4 & Enterococcus & 2 & Citrobacter & 4 & Staphylococcus \\
\hline 3 & Staphylococcus & 2 & Enterococcus & 2 & Streptococcus \\
\hline 2 & Enterobacter & 2 & Klebsiella & 2 & Enterococcus \\
\hline 2 & Pseudomonas & 2 & Serratia & I & Escherichia \\
\hline I & Klebsiella & 2 & Staphylococcus & I & Leclercia \\
\hline I & Serratia & 2 & Streptococcus & I & Proteus \\
\hline I & Citrobacter & 1 & Proteus & I & Pseudomonas \\
\hline \multirow[t]{2}{*}{ I } & Acinetobacter & I & Pseudomonas & 1 & Acinetobacter \\
\hline & & I & Escherichia & I & Enterobacter \\
\hline
\end{tabular}

Subject's medical records were examined, and the positive culture nearest to the date of sample collection for molecular analysis was considered. All thirty (30) subjects except for one (I) subject in the P group had a culture recorded in their medical records. The number of subjects within each group to culture positive for a bacterial genus is listed next to the genus. Many of the subjects were cultured for both aerobes and anaerobes, but the clinical laboratories reported no obligate anaerobes. 
new dimension to Koch's postulates. These finding also dramatically highlight the failings of culture methods to identify major populations of importance within each of the wound types.

\section{Conclusion}

The primary contrasts we see in these data are the differences found in bacterial populations within wound types using culture (Table 10) and molecular analyses (Tables 1 , $2,3,4,5,6,7,8,9)$. Here we show that culturing failed to identify major contributing populations, especially strict anaerobes, within the given wound types. Standard culturing techniques are inherently biased as they only examine only the $1 \%$ of all microorganisms which are able to grow fairly rapidly in pure culture. Culturing also requires several days before the culturable bacteria can be identified whereas molecular methods such as PCR can typically be completed within several hours. In addition, certain of the isolates we have shown are primary populations within a wound type, may never be cultured in the laboratory due to reduced metabolic activity, obligate cooperation with other bacteria, requirements for specialized nutrients, or growth in specific environmental conditions [106]. Molecular methods unlike culture methods also have more potential to provide quantitative data. Arguably, we have shown that molecular methods will allow populations residing within biofilms to be more fully characterized. The continued development of molecular methods may lead to vastly improved tools for diagnostics that will identify and provide quantification of the diverse species potentially present in chronic wounds thereby allowing physicians to better tailor their treatment to each patient's unique pathogenic biofilm populations. This dramatically highlights the need to move microbiological analyses of chronic wound pathogenic biofilms toward molecular approaches.

If clinicians can gain a better understanding of the wound's microbiota, it will give us a greater understanding of the wound's ecology and will allow us to better manage the wound. It is important to consider the bacterial populations within pathogenic biofilms for many reasons. These reasons typically relate to the fact that the higher bacterial population diversity within a pathogenic biofilm provides the bacterial community as a whole with an enhanced ability to persist and thrive in a variety of antagonistic situations, even in spite of combined host and medicinal attack [107]. The current study has shown that a wide variety of bacteria with different physiological and phenotypic preferences are common as part of pathogenic biofilm communities in chronic wounds. Additionally, we can see that different types of wounds may have different bacterial populations that are prevalent. Thus, the CWPB in one wound or wound type may indicate a therapy that is different than that indicated in another wound or wound type. As noted previously, such conclusions are beyond the scope of this survey but are suggested by the results. These conclusions also provide direction for future research. The use of traditional culture techniques are widely used, but we and others have consistantly demonstrate that they are not likely to be the best way to elucidate the bacterial populations within CWPB.

\section{Methods}

Biofilms from a total of 30 chronic wound patients were included in this survey study. A total of 30 chronic wounds were sampled and grouped into one of three categories of wounds: venous leg ulcers (V), diabetic foot ulcers (D), or pressure ulcers (P). To identify the microbial populations that occur in these types of wounds and to gain a preliminary understanding of their relative importance, we took advantage of three powerful molecular approaches that included PRADS [108], FRACS [109], and PRADS [110]. These techniques allowed the bacterial diversity that occurs within these CWPB types to be evaluated.

\section{Protocol for subject enrollment, DNA extraction, and Sample Preparation}

Under the guidance of IBR protocols, chronic wounds of 30 subjects treated at the Southwest Regional Wound Care Center (Lubbock, Texas) were debrided as per standard of care; the debridement samples were collected with sterile tools into sterile collection tubes and frozen until processing for DNA extraction. Samples from 10 subjects with venous leg ulcers, 10 subjects with diabetic foot ulcers, and 10 subjects with pressure (decubitus) ulcers were included in this study. Debridement samples (300 mg \pm $150 \mathrm{mg}$ ) were collected into Lysing Matrix E tubes from the FastDNA ${ }^{\circledast}$ SPIN for Soil Kit from MP Biomedicals LLC (Solon, OH). The tubes were frozen at $-70^{\circ} \mathrm{C}$ until DNA extraction could be performed. When DNA extraction was performed, the samples were removed from the freezer and allowed to thaw at room temperature. Subsequently, the DNA extraction protocol for the kit was followed with the exception that human debridement samples were used in place of soil samples. The extracted sample DNA was stored at $-70^{\circ} \mathrm{C}$. After measuring the relative concentration of bacterial DNA present based upon 16s quantitative PCR using 16S Universal Eubacterial primers 530F (5'-GTG CCA GCM GCN GCG G) and 1100R (5'-GGG TTN CGN TCG TTG), the 10 samples from each of the three wound groups were pooled at equal bacterial DNA ratios to create three pools of DNA, each representing a major category of chronic wound.

\section{Partial ribosomal amplification and pyrosequencing (PRAPS)}

The modified 16S Eubacterial primers 530F and 1100R were used for amplifying the $600 \mathrm{bp}$ region of $16 \mathrm{~S}$ rRNA 
genes. The primer pair used for 454 Amplicon Sequencing was designed with special Fusion Primers at the 5 ' end of each primer as follows: 530F-A (5'-GCC TCC CTC GCG CCA TCA GGT GCC AGC MGC NGC GG) and 1100R-B (5'-GCC TTG CCA GCC CGC TCA GGG GTT NCG NTC GTT G). All wound DNA samples were diluted to $100 \mathrm{ng} /$ $\mu \mathrm{l}$. A $100 \mathrm{ng}$ aliquot of sample DNA was used for a $50 \mu \mathrm{l}$ PCR reaction. HotStarTaq Plus Master Mix Kit (QIAGEN, CA, USA) was used for PCR under the following conditions: $94^{\circ} \mathrm{C}$ for 3 minutes followed by 32 cycles of $94^{\circ} \mathrm{C}$ for 30 seconds; $60^{\circ} \mathrm{C}$ for 40 seconds and $72^{\circ} \mathrm{C}$ for 1 minute; and a final elongation step at $72^{\circ} \mathrm{C}$ for 5 minutes. PCR products were purified using the PSI $\Psi$ Clone PCR 96 Kit (Princeton Separations Inc, Freehold, NJ). Following PCR amplification, samples were normalized in concentration and sent on dry ice to the Medical Biofilm Research Institute [111] for pyrosequencing using genome sequencer FLX system's standard amplicon sequencing protocols (F. Hoffmann-La Roche Ltd, Basel, Switzerland).

\section{Full ribosomal amplification, cloning and Sanger sequencing (FRACS)}

The Eubacterial 16S primers 27F (5'-AGA GTT TGA TCM TGG CTC AG) and 1525R (5'-AAG GAG GTG WTC CAR CC) were synthesized by Integrated DNA Technologies (Coralville, IA). These primers amplify roughly $1500 \mathrm{bp}$ spanning almost the entire $16 \mathrm{~S}$ gene. A total of $100 \mathrm{ng}$ of sample DNA was used for each $50 \mu$ PCR reaction. HotStarTaq Plus Master Mix Kit (Qiagen, Valencia, CA) was used for PCR using the following conditions: $94^{\circ} \mathrm{C}$ for 3 minutes followed by 35 cycles of $94^{\circ} \mathrm{C}$ for 30 seconds, $52^{\circ} \mathrm{C}$ for 40 seconds, and $72^{\circ} \mathrm{C}$ for 2 minutes. A final elongation step at $72^{\circ} \mathrm{C}$ for 10 minutes was also included. The amplified fragments were subcloned into the pGEMT Easy Vector (Promega, Madison, WI) and transformed into a competent $E$. coli $\mathrm{K} 12$ strain. Following blue/white screening using standard methods, 200 clones from each library were isolated and subcultured. The plasmid DNA was extracted by using a QIAprep Spin Miniprep Kit (Qiagen, Valencia, CA). Bidirectional sequencing using $\mathrm{T} 7$ and SP6 primers was performed by Agencourt Technologies (Beverly, MA).

\section{Partial Ribosomal Amplification, DGGE, and Sanger sequencing (PRADS)}

The 16S Eubacterial primers 1070F (5'-ATG GCT GTC GTC AGC T) and 1492R+GC (5'-GCC GCC TGC AGC CCG CGC CCC CCG TGC CCC CGC CCC GCC GCC GGC CCG GGC GCC TTA CCC TTG TTA CGA CTT) were synthesized by Integrated DNA Technologies (Coralville, IA). These primers produced an approximately $450 \mathrm{bp}$ $16 \mathrm{~S}$ ribosomal DNA (rDNA) amplicon with a GC clamp to be analyzed by denaturing gradient gel electrophoresis (DGGE). PCR reactions ( $50 \mu \mathrm{l}$ of sample DNA) were per- formed using 2× PCR Master Mix (Promega, Madison, WI). Each reaction mixture consisted of $1.5 \mathrm{mM} \mathrm{MgCl} 2$, $200 \mu \mathrm{M}$ of each dNTP, $0.5 \mu \mathrm{M}$ of both the 1070F and 1492R+GC primers, $0.025 \mathrm{U} / \mu \mathrm{l}$ Taq DNA polymerase, and 100 ng template DNA.

Denaturing gradient gel electrophoresis (DGGE) was performed on the 16S amplicons described above using the DCode $^{\mathrm{TM}}$ DGGE system (Bio-rad). A 40\%-70\% denaturing gradient was optimal for separation of the approximately 450 bp $16 \mathrm{~S}$ amplicons, where $7 \mathrm{M}$ urea and $40 \%$ formamide is defined as $100 \%$. Gels also contained an $8 \%-12 \%$ acrylamide gradient with a $12 \%$ native stacking gel. Different volumes of each sample were loaded for optimal visualization of bands with varying intensities. The gel was run at $60 \mathrm{~V}$ for 20 hours and was then stained with SYBR Gold ${ }^{\circledR}$ (Molecular Probes, Invitrogen, Carlsbad, CA) and visualized with a FluorChem ${ }^{\mathrm{TM}} 8800$ fluorescence imager (Alpha Innotech Inc. San Leandro, CA). Nineteen predominant bands that could be visualized by eye were excised using a sterile, disposable scalpel and placed in 20 $\mu \mathrm{l}$ TE buffer (Figure 1). This included 4 bands from the venous leg ulcer group (group V), 8 from the diabetic foot ulcer group (group D), and 6 from the pressure ulcer group (group P).

The TOPO TA Cloning ${ }^{\circledR}$ kit (Invitrogen Inc. Carlsbad, CA) was used to clone the DNA from the excised DGGE bands $\left(\mathrm{pCR}^{\circledR}\right.$ 2.1-TOPO ${ }^{\circledR}$ vector and One Shot Chemically Competent $E$. coli cells). The maximum amount of DNA $(4 \mu \mathrm{l}$ diffused DNA in TE buffer) was used in each of the cloning reactions following the manufacture's instructions. Twelve clones per band were selected and grown overnight in $250 \mu \mathrm{l} \mathrm{LB}$ broth containing $50 \mu \mathrm{g} / \mathrm{ml}$ kanamycin in 96 well plates. The same $50 \mu \mathrm{l}$ PCR reaction was prepared as described above using the M13F and M13R primer set instead of $1070 \mathrm{~F}$ and $1492 \mathrm{R}+\mathrm{GC}$ and $5 \mu \mathrm{l}$ of the overnight culture was added to each $50 \mu \mathrm{l}$ PCR reaction as the template DNA. The initial $96^{\circ} \mathrm{C}$ denaturing step was sufficient to rupture the $E$. coli cells, releasing its DNA as the starting template. These PCR products were then sequenced by the University of Washington's HighThroughput Genomics Unit (Seattle, WA).

\section{Culturing}

Samples were not collected in parallel with samples collected for the PRAPS, FRACS, or PRADS; but culture results were instead collected retrospectively from the subjects' medical records. All samples were collected under IBR protocols. This information is provided as a contrast to the type of data normally collected from wounds. Results were examined from each subject's medical record. The culture results were collected usually within a week of the samples that was collected for the PRAPS, FRACS, and PRADS analyses. Sharp debridement from the subject's 
wound was placed in thioglycolate broth with indicator (Hardy Diagnostics, Santa Maria, CA) and incubated at $35^{\circ} \mathrm{C}$ for up to 24 hours with the lid tightly closed before being transferred to a CLIA certified microbiology laboratory for thorough aerobic and anaerobic culture analyses. Bacteria were identified using Gram stains, non-selective and selective/differential media, and biochemical tests.

\section{Bioinformatics}

Assembly, including vector scanning, quality analysis, and consensus calling, of sequencing data was performed using Seq-Man Pro assembler (DNAstar Madison, WI). Sequences were assembled using SeqMan Pro Assembler at $96 \%$ similarity, match size of 25 , match spacing of 50 , minimum sequence length of $100,0.0$ and 0.7 gap and gap extension penalties, and a minimum mismatch of 8 at end bases. Multiple alignments were performed with MegAlign (DNAstar Madison, WI). BLAST analyses were performed using WND.BLAST [112] and a custom 16S ribosomal database derived from RDPII version 9 $[113,114]$. The database was first parsed with a custom script to provide genus and species names as hit definitions following BLAST analyses. For FRACS E-values < 10E-100 were considered acceptable for determining genus, while hits of $\mathrm{E}=0.0$ and associated full alignments $>1400$ bp were considered acceptable for determining genus and species. For PRADS and PRAPS all species determinations are considered putative, E-values of 10100 are considered acceptable for determining genus, while E-values better than 10-140, along with full input sequence alignments, and genus/species agreement of all similarly scoring top hits were required to list a putative species.

\section{Authors' contributions}

SED was responsible for primary conception of the methods, project management, data interpretation, and development and approval of the final version of the manuscript. YS helped develop methods, performed most of the laboratory studies, and data compilation. PS and GJ performed DGGE and all associated writing and data interpretations. DR helped with interpretation of results, compiling data, and writing of early drafts of the manuscript. RW was vital in developing the project concepts, interpretation of results and approval of final draft of the manuscript.

\section{Acknowledgements}

USDA disclaimer: The use of trade, firm, or corporation names in this publication is for the information and convenience of the reader. Such use does not constitute an official endorsement or approval by the United States Department of Agriculture. Dr. Dowd's work on this project was performed as part of a USDA trust agreement for development of next generation sequencing technologies for the study of host-pathogen interactions and diversity.

\section{References}

I. Nickel JC, Heaton J, Morales A, Costerton JW: Bacterial biofilm in persistent penile prosthesis-associated infection. J Urol 1986 , 135:586-588.

2. Buret $\mathrm{A}, \mathrm{W}$ ard $\mathrm{KH}$, Olson ME, Costerton JW: An in vivo model to study the pathobiology of infectious biofilms on biomaterial surfaces. J Biomed Mater Res 1991, 25:865-874.

3. Holland SP, Pulido JS, Miller D, Ellis B, Alfonso E, Scott M, Costerton JW: Biofilm and scleral buckle-associated infections. A mechanism for persistence. Ophthalmology 1991, 98:933-938.

4. Ward KH, Olson ME, Lam K, Costerton JW: Mechanism of persistent infection associated with peritoneal implants. J Med Microbiol 1992, 36:406-4I3.

5. Donlan RM, Costerton JW: Biofilms: survival mechanisms of clinically relevant microorganisms. Clin Microbiol Rev 2002, I5:167-193.

6. Costerton JW: Biofilm theory can guide the treatment of device-related orthopaedic infections. Clin Orthop Relat Res 2005:7-II.

7. Cho SH, Naber K, Hacker J, Ziebuhr W: Detection of the icaADBC gene cluster and biofilm formation in Staphylococcus epidermidis isolates from catheter-related urinary tract infections. Int J Antimicrob Agents 2002, 19:570-575.

8. Crump JA, Collignon PJ: Intravascular catheter-associated infections. Eur J Clin Microbiol Infect Dis 2000, I 9: I-8.

9. Malaisrie SC, Malekzadeh S, Biedlingmaier JF: In vivo analysis of bacterial biofilm formation on facial plastic bioimplants. Laryngoscope 1998, I 08:1733-1738.

10. Ando E, Monden K, Mitsuhata R, Kariyama R, Kumon H: Biofilm formation among methicillin-resistant Staphylococcus aureus isolates from patients with urinary tract infection. Acta Med Okayama 2004, 58:207-2I4.

II. Wagner C, Kondella K, Bernschneider T, Heppert V, Wentzensen A, Hansch GM: Post-traumatic osteomyelitis: analysis of inflammatory cells recruited into the site of infection. Shock 2003, 20:503-510.

12. Vasudevan P, Nair MK, Annamalai T, Venkitanarayanan KS: Phenotypic and genotypic characterization of bovine mastitis isolates of Staphylococcus aureus for biofilm formation. Vet Microbiol 2003, 92:179-185.

13. Nickel JC, Emtage J, Costerton JW: Ultrastructural microbial ecology of infection-induced urinary stones. J Urol 1985, 1 33:622-627.

14. Nickel JC, Costerton JW, McLean RJ, Olson M: Bacterial biofilms: influence on the pathogenesis, diagnosis and treatment of urinary tract infections. J Antimicrob Chemother 1994, 33 Suppl A:3|-4I.

15. Costerton JW, Stewart PS, Greenberg EP: Bacterial biofilms: a common cause of persistent infections. Science 1999, 284: $1318-1322$.

16. Costerton JW: Cystic fibrosis pathogenesis and the role of biofilms in persistent infection. Trends Microbiol 2001, 9:50-52.

17. Leid JG, Costerton JW, Shirtliff ME, Gilmore MS, Engelbert M: Immunology of Staphylococcal biofilm infections in the eye: new tools to study biofilm endophthalmitis. DNA Cell Biol 2002, 2 I:405-4I3.

18. Percival SL, Bowler PG, Dolman J: Antimicrobial activity of silvercontaining dressings on wound microorganisms using an in vitro biofilm model. Int Wound J 2007, 4:|86-I9l.

19. Ryan TJ: Infection following soft tissue injury: its role in wound healing. Curr Opin Infect Dis 2007, 20: I24-I28.

20. Ngo Q, Vickery K, Deva AK: Pr2 I role of bacterial biofilms in chronic wounds. ANZJ Surg 2007, 77 Suppl I:A66.

21. Horrocks A: Prontosan wound irrigation and gel: management of chronic wounds. Br J Nurs 2006, I 5(22): I222-I228.

22. Davis SC, Martinez L, Kirsner R: The diabetic foot: the importance of biofilms and wound bed preparation. Curr Diab Rep 2006, 6:439-445.

23. Saye DE: Recurring and antimicrobial-resistant infections:considering the potential role of biofilms in clinical practice. Ostomy Wound Manage 2007, 53:46-8, 50, 52.

24. James GA, Swogger E, Wolcott R, Pulcini ED, Secor P, Sestrich J, Costerton JW, Stewart PS: Biofilms in chronic wounds. Wound Repair Regen 2008, I 6(I):37-44. 
25. Gjodsbol K, Christensen J, Karlsmark T, Jorgensen B, Klein BM, Krogfelt KA: Multiple bacterial species reside in chronic wounds: a longitudinal study. Int Wound J 2006, 3:225-23 I.

26. Ashton J: Managing leg and foot ulcers: the role of Kerraboot. BrJ Community Nurs 2004, 9:S26-S30.

27. Bauer SM, Bauer RJ, Velazquez OC: Angiogenesis, vasculogenesis, and induction of healing in chronic wounds. Vasc Endovascular Surg 2005, 39:293-306.

28. Boyko DA, Rowley-Jones D: Stress ulceration. Br J Hosp Med I985, 34: $186-187$

29. Bradley M, Cullum N, Nelson EA, Petticrew M, Sheldon T, Torgerson $D$ : Systematic reviews of wound care management: (2) Dressings and topical agents used in the healing of chronic wounds. Health Technol Assess 1999, 3: I-35.

30. Bradley M, Cullum N, Sheldon T: The debridement of chronic wounds: a systematic review. Health Technol Assess 1999, 3:iii-78.

3I. Brem H, Kirsner RS, Falanga V: Protocol for the successful treatment of venous ulcers. Am J Surg 2004, I 88: I-8.

32. Burton CS: Venous ulcers. Am J Surg 1994, 167:37S-40S

33. Eaglstein WH, Falanga V: Chronic wounds. Surg Clin North Am 1997, 77:689-700.

34. Evans $D$, Land $L$ : Topical negative pressure for treating chronic wounds: a systematic review. Br J Plast Surg 200I, 54:238-242.

35. Falanga $\mathrm{V}$ : The chronic wound: impaired healing and solutions in the context of wound bed preparation. Blood Cells Mol Dis 2004, 32:88-94.

36. Falanga V: Wound healing and chronic wounds. J Cutan Med Surg 1998, 3 SuppI I:SI-S5.

37. Jeffcoate W], Harding KG: Diabetic foot ulcers. Lancet 2003 , $361: 1545-1551$.

38. Beckrich K, Aronovitch SA: Hospital-acquired pressure ulcers: a comparison of costs in medical vs. surgical patients. Nurs Econ 1999, 17:263-271.

39. Akiyama $\mathrm{H}$, Kanzaki $\mathrm{H}$, Tada J, Arata J: Staphylococcus aureus infection on cut wounds in the mouse skin: experimental staphylococcal botryomycosis. J Dermatol Sci 1996, I I:234-238.

40. Edwards R, Harding KG: Bacteria and wound healing. Curr Opin Infect Dis 2004, 17:91-96.

41. Valdez JC, Peral MC, Rachid M, Santana M, Perdigon G: Interference of Lactobacillus plantarum with Pseudomonas aeruginosa in vitro and in infected burns: the potential use of probiotics in wound treatment. Clin Microbiol Infect 2005, I I:472-479.

42. White RJ, Cutting K, Kingsley A: Topical antimicrobials in the control of wound bioburden. Ostomy Wound Manage 2006 52:26-58.

43. Williams C: Wound care: Askina Transorbent and Askina Biofilm Transparent. Br J Nurs 2000, 9:304-307.

44. Wysocki $A B$ : Evaluating and managing open skin wounds: colonization versus infection. AACN Clin Issues 2002, 13:382-397.

45. Church D, Elsayed S, Reid O, Winston B, Lindsay R: Burn wound infections. Clin Microbiol Rev 2006, 19:403-434.

46. Agnihotri N, Gupta V, Joshi RM: Aerobic bacterial isolates from burn wound infections and their antibiograms--a five-year study. Burns 2004, 30:24I-243

47. Armour AD, Shankowsky HA, Swanson T, Lee J, Tredget EE: The impact of nosocomially-acquired resistant Pseudomonas aeruginosa infection in a burn unit. J Trauma 2007, 63: I64-17I.

48. Landi F, Onder G, Russo A, Bernabei R: Pressure ulcer and mortality in frail elderly people living in community. Arch Gerontol Geriatr 2007, 44 Suppl I:217-223.

49. Landi F, Sgadari A, Bernabei R: Pressure ulcers. Ann Intern Med 1996, I 25:422.

50. Perencevich EN, Sands KE, Cosgrove SE, Guadagnoli E, Meara E, Platt $R$ : Health and economic impact of surgical site infections diagnosed after hospital discharge. Emerg Infect Dis 2003, 9:196-203

5I. Davis LE, Cook G, Costerton JW: Biofilm on ventriculo-peritoneal shunt tubing as a cause of treatment failure in coccidioidal meningitis. Emerg Infect Dis 2002, 8:376-379.

52. Ramsey SD, Newton K, Blough D, McCulloch DK, Sandhu N, Wagne $\mathrm{EH}$ : Patient-level estimates of the cost of complications in diabetes in a managed-care population. Pharmacoeconomics 1999, 16:285-295.

53. Ramsey SD, Newton K, Blough D, McCulloch DK, Sandhu N, Reiber $\mathrm{GE}$, Wagner $\mathrm{EH}$ : Incidence, outcomes, and cost of foot ulcers in patients with diabetes. Diabetes Care 1999, 22:382-387.
54. Boyko EJ, Ahroni JH, Stensel V, Forsberg RC, Davignon DR, Smith DG: A prospective study of risk factors for diabetic foot ulcer. The Seattle Diabetic Foot Study. Diabetes Care 1999, 22:1036-1042.

55. Boyko EJ, Ahroni JH, Smith DG, Davignon D: Increased mortality associated with diabetic foot ulcer. Diabet Med 1996, I3:967-972.

56. McGuckin M, Goldman R, Bolton L, Salcido R: The clinical relevance of microbiology in acute and chronic wounds. Adv Skin Wound Care 2003, 16:12-23.

57. Thomson PD: Immunology, microbiology, and the recalcitrant wound. Ostomy Wound Manage 2000, 46:77S-82S.

58. Davies CE, Hill KE, Wilson MJ, Stephens P, Hill CM, Harding KG, Thomas DW: Use of 165 ribosomal DNA PCR and denaturing gradient gel electrophoresis for analysis of the microfloras of healing and nonhealing chronic venous leg ulcers. J Clin Microbiol 2004, 42:3549-3557.

59. Bradshaw DJ, Marsh PD, Allison C, Schilling KM: Effect of oxygen, inoculum composition and flow rate on development of mixed-culture oral biofilms. Microbiology 1996, 142 ( Pt 3):623-629.

60. Dunsmore B, Youldon J, Thrasher DR, Vance I: Effects of nitrate treatment on a mixed species, oil field microbial biofilm. J Ind Microbiol Biotechnol 2006, 33:454-462.

61. Mayrand D, McBride BC: Exological relationships of bacteria involved in a simple, mixed anaerobic infection. Infect Immun 1980, 27:44-50.

62. Stoodley P, Wilson S, Hall-Stoodley L, Boyle JD, Lappin-Scott HM, Costerton JW: Growth and detachment of cell clusters from mature mixed-species biofilms. Appl Environ Microbiol 200I, 67:5608-56/3.

63. Edwards RA, Rodriguez-Brito B, Wegley L, Haynes M, Breitbart M, Peterson DM, Saar MO, Alexander S, Alexander EC Jr., Rohwer F: Using pyrosequencing to shed light on deep mine microbial ecology. BMC Genomics 2006, 7:57.

64. Luna RA, Fasciano LR, Jones SC, Boyanton BL, Ton TT Jr., Versalovic J: DNA Pyrosequencing-Based Bacterial Pathogen Identification in a Pediatric Hospital Setting. J Clin Microbiol 2007.

65. Jonasson J, Olofsson M, Monstein HJ: Classification, identification and subtyping of bacteria based on pyrosequencing and signature matching of 16 s rDNA fragments. 2002. APMIS 2007, I I 5:668-677.

66. Gharizadeh B, Kalantari M, Garcia CA, Johansson B, Nyren P: Typing of human papillomavirus by pyrosequencing. Lab lnvest $200 \mathrm{I}$, 81:673-679.

67. Trama JP, Mordechai E, Adelson ME: Detection and identification of Candida species associated with Candida vaginitis by realtime PCR and pyrosequencing. Mol Cell Probes 2005, 19: I45-I52

68. Jordan JA, Butchko AR, Durso MB: Use of pyrosequencing of I6S rRNA fragments to differentiate between bacteria responsible for neonatal sepsis. J Mol Diagn 2005, 7:105-II0.

69. Hopkins KL, Arnold C, Threlfall EJ: Rapid detection of gyrA and parC mutations in quinolone-resistant Salmonella enterica using Pyrosequencing technology. J Microbiol Methods 2007, 68:163-171.

70. Rossler D, Ludwig W, Schleifer KH, Lin C, McGill TJ, Wisotzkey JD, Jurtshuk PJr., Fox GE: Phylogenetic diversity in the genus Bacillus as seen by 165 rRNA sequencing studies. Syst Appl Microbiol 1991, 14:266-269.

7I. Egli K, Bosshard F, Werlen C, Lais P, Siegrist H, Zehnder AJ, Van M Jr.: Microbial composition and structure of a rotating biological contactor biofilm treating ammonium-rich wastewater without organic carbon. Microb Ecol 2003, 45:419-432.

72. Schabereiter-Gurtner C, Saiz-limenez C, Pinar G, Lubitz W, Rolleke $S$ : Phylogenetic I6S rRNA analysis reveals the presence of complex and partly unknown bacterial communities in Tito Bustillo cave, Spain, and on its Palaeolithic paintings. Environ Microbiol 2002, 4:392-400.

73. Schmeisser C, Stockigt C, Raasch C, Wingender J, Timmis KN, Wenderoth DF, Flemming HC, Liesegang H, Schmitz RA, Jaeger KE, Streit WR: Metagenome survey of biofilms in drinking-water networks. Appl Environ Microbiol 2003, 69:7298-7309.

74. Redkar R, Kalns J, Butler W, Krock L, McCleskey F, Salmen A, Jr PE, DelVecchio $V$ : Identification of bacteria from a non-healing diabetic foot wound by 16 S rDNA sequencing. Mol Cell Probes 2000, 14:163-169. 
75. Yin J, Chen $Y X$, Liu H, Wang YP: [Preliminary application of PCR-DGGE to analyzing microbial diversity in biofilters treating air loaded with ammonia]. Huan Jing Ke Xue 2004, 25:II-I5.

76. Rasiah IA, Wong L, Anderson SA, Sissons CH: Variation in bacterial DGGE patterns from human saliva: over time, between individuals and in corresponding dental plaque microcosms. Arch Oral Biol 2005, 50:779-787.

77. Mertoglu B, Calli B, Girgin E, Inanc B, Ozturk I: Comparative anal$y$ sis of nitrifying bacteria in full-scale oxidation ditch and aerated nitrification biofilter by using fluorescent in situ hybridization (FISH) and denaturing gradient gel electrophoresis (DGGE). J Environ Sci Health A Tox Hazard Subst Environ Eng 2005, 40:937-948.

78. Lyautey E, Lacoste B, Ten-Hage L, Rols JL, Garabetian F: Analysis of bacterial diversity in river biofilms using I6S rDNA PCRDGGE: methodological settings and fingerprints interpretation. Water Res 2005, 39:380-388.

79. Sanchez O, Gasol JM, Massana R, Mas J, Pedros-Alio C: COMPARISON OF DIFFERENT DGGE (DENATURING GRADIENT GEL ELECTROPHORESIS) PRIMER SETS FOR THE STUDY OF MARINE BACTERIOPLANKTON COMMUNITIES. Appl Environ Microbiol 2007.

80. Xiao Y, Yang ZH, Zeng GM, Ma YH, Liu YS, Wang RJ, Xu ZY: [Bacterial diversity in sequencing batch biofilm reactor (SBBR) for landfill leachate treatment using PCR-DGGE]. Huan jing Ke Xue 2007, 28:1095-II01.

8I. Duarte IC, Oliveira LL, Saavedra NK, Fantinatti-Garboggini F, Oliveira VM, Varesche MB: Evaluation of the microbial diversity in a horizontal-flow anaerobic immobilized biomass reactor treating linear alkylbenzene sulfonate. Biodegradation 2007.

82. Kim GT, Webster G, Wimpenny JW, Kim BH, Kim HJ, Weightman AJ: Bacterial community structure, compartmentalization and activity in a microbial fuel cell. J Appl Microbiol 2006, I 0 I:698-710.

83. Webster NS, Negri AP: Site-specific variation in Antarctic marine biofilms established on artificial surfaces. Environ Microbiol 2006, 8: I I77-I I 90.

84. McBain AJ, Bartolo RG, Catrenich CE, Charbonneau D, Ledder RG, Rickard AH, Symmons SA, Gilbert P: Microbial characterization of biofilms in domestic drains and the establishment of stable biofilm microcosms. Appl Environ Microbiol 2003, 69: I77-I85.

85. Li Y, Ku CY, Xu J, Saxena D, Caufield PW: Survey of oral microbial diversity using PCR-based denaturing gradient gel electrophoresis. J Dent Res 2005, 84:559-564.

86. Brook I, Frazier EH: Aerobic and anaerobic microbiology of chronic venous ulcers. Int J Dermatol 1998, 37:426-428.

87. Urbancic-Rovan V, Gubina M: Bacteria in superficial diabetic foot ulcers. Diabet Med 2000, 17:8I4-8I5.

88. Bowler PG, Davies B]: The microbiology of infected and noninfected leg ulcers. Int / Dermatol 1999, 38:573-578.

89. Howell-Jones RS, Wilson MJ, Hill KE, Howard AJ, Price PE, Thomas DW: A review of the microbiology, antibiotic usage and resistance in chronic skin wounds. J Antimicrob Chemother 2005, 55:143-149,

90. Schmidt K, Debus ES, St ], Ziegler U, Thiede A: Bacterial population of chronic crural ulcers: is there a difference between the diabetic, the venous, and the arterial ulcer? Vasa 2000 , 29:62-70.

91. Bowler PG, Davies BJ, Jones SA: Microbial involvement in chronic wound malodour. / Wound Care 1999, 8:216-218.

92. Brook I: Microbiological studies of decubitus ulcers in children. J Pediatr Surg 1991, 26:207-209.

93. Hansson C, Hoborn J, Moller A, Swanbeck G: The microbial flora in venous leg ulcers without clinical signs of infection. Repeated culture using a validated standardised microbiological technique. Acta Derm Venereol 1995, 75:24-30.

94. Kontiainen S, Rinne E: Bacteria in ulcera crurum. Acta Derm Venereol 1988, 68:240-244.

95. Davies CE, Wilson MJ, Hill KE, Stephens P, Hill CM, Harding KG, Thomas DW: Use of molecular techniques to study microbial diversity in the skin: chronic wounds reevaluated. Wound Repair Regen 200I, 9:332-340.

96. Gao Z, Tseng CH, Pei Z, Blaser MJ: Molecular analysis of human forearm superficial skin bacterial biota. Proc Natl Acad Sci U S A 2007, 104:2927-2932.
97. Dekio I, Hayashi H, Sakamoto M, Kitahara M, Nishikawa T, Suematsu $M$, Benno $Y$ : Detection of potentially novel bacterial components of the human skin microbiota using culture-independent molecular profiling. J Med Microbiol 2005, 54: I23I-I 238.

98. Trengove NJ, Stacey MC, McGechie DF, Mata S: Qualitative bacteriology and leg ulcer healing. J Wound Care 1996, 5:277-280.

99. Bradshaw DJ, Marsh PD, Watson GK, Allison C: Role of Fusobacterium nucleatum and coaggregation in anaerobe survival in planktonic and biofilm oral microbial communities during aeration. Infect Immun 1998, 66:4729-4732.

100. Rasmussen K, Lewandowski Z: Microelectrode measurements of local mass transport rates in heterogeneous biofilms. Biotechnol Bioeng 1998, 59:302-309.

101. Brook I: Role of anaerobic bacteria in aortofemoral graft infection. Surgery 1988, 104:843-845.

102. Brook I: Role of encapsulated anaerobic bacteria in synergistic infections. Crit Rev Microbiol 1987, I 4: I7I-193.

103. Sundqvist GK, Eckerbom MI, Larsson AP, Sjogren UT: Capacity of anaerobic bacteria from necrotic dental pulps to induce purulent infections. Infect Immun 1979, 25:685-693.

104. Bowler PG, Duerden BI, Armstrong DG: Wound microbiology and associated approaches to wound management. Clin Microbiol Rev 200I, I4:244-269.

105. Rotstein OD, Kao J: The spectrum of Escherichia coli--Bacteroides fragilis pathogenic synergy in an intraabdominal infection model. Can J Microbiol 1988, 34:352-357.

106. Veeh RH, Shirtliff ME, Petik JR, Flood JA, Davis CC, Seymour JL, Hansmann MA, Kerr KM, Pasmore ME, Costerton JW: Detection of Staphylococcus aureus biofilm on tampons and menses components. J Infect Dis 2003, 188:519-530.

107. Boles BR, Thoendel M, Singh PK: Self-generated diversity produces "insurance effects" in biofilm communities. Proc Nat Acad Sci U S A 2004, 101:16630-16635.

108. Ronaghi M, Nygren M, Lundeberg J, Nyren P: Analyses of secondary structures in DNA by pyrosequencing. Anal Biochem 1999, 267:65-7I.

109. Messing J, Crea R, Seeburg PH: A system for shotgun DNA sequencing. Nucleic Acids Res 1981, 9:309-321.

1 10. Sheffield VC, Fishman GA, Beck JS, Kimura AE, Stone EM: Identification of novel rhodopsin mutations associated with retinitis pigmentosa by GC-clamped denaturing gradient gel electrophoresis. Am J Hum Genet 1991, 49:699-706.

III. Institute MBR: http://www.medicalbiofilm.org. Lubbock, TX 2008 [http://www.medicalbiofilm.org].

112. Dowd SE, Zaragoza J, Rodriguez JR, Oliver MJ, Payton PR: Windows .NET Network Distributed Basic Local Alignment Search Toolkit (W.ND-BLAST). BMC Bioinformatics 2005, 6:93.

1 13. Maidak BL, Cole JR, Lilburn TG, Parker CT Jr., Saxman PR, Farris RJ, Garrity GM, Olsen GJ, Schmidt TM, Tiedje JM: The RDP-II (Ribosomal Database Project). Nucleic Acids Res 200I, 29: I73-174.

1 14. Olsen G], Overbeek R, Larsen N, Marsh TL, McCaughey MJ, Maciukenas MA, Kuan WM, Macke TJ, Xing Y, Woese CR: The Ribosomal Database Project. Nucleic Acids Res 1992, 20 Suppl:2199-2200.

Publish with Bio Med Central and every scientist can read your work free of charge

"BioMed Central will be the most significant development for disseminating the results of biomedical research in our lifetime. "

Sir Paul Nurse, Cancer Research UK

Your research papers will be:

- available free of charge to the entire biomedical community

- peer reviewed and published immediately upon acceptance

- cited in PubMed and archived on PubMed Central

- yours - you keep the copyright
BioMedcentral 